\title{
Giuseppe Piazzi and the Discovery of Ceres
}

\author{
G. Foderà Serio \\ Universita' di Palermo
}

\author{
A. Manara \\ Osservatorio Astronomico di Brera \\ P. Sicoli \\ Osservatorio Astronomico di Sormano
}

\begin{abstract}
In this chapter we focus on the circumstances that led Giuseppe Piazzi (1746-1826) to discover the first asteroid, Ceres, on January 1, 1801. Through the examination of published and archival documentation, we shed light on the reaction of the astronomical community at the announcement of the discovery and on Piazzi's puzzling behavior. In the end, we briefly discuss the discoveries of Pallas, Juno, and Vesta and the theories put forward to explain their nature.
\end{abstract}

\section{INTRODUCTION}

Gioacchino Giuseppe Maria Ubaldo Nicolò Piazzi was born in Ponte, Valtellina, July 16, 1746, to one of the wealthiest families of the region. The penultimate of 10 sons, most of whom died as children, his parents worried about his health and for this reason quickly baptized him at home. The register of baptisms of St. Maurizio Church clearly specifies "ob imminens vitae periculum," or "because of impending danger of death" (Maineri, 1871; Invernizzi et al., 2001).

Following the tradition that encouraged younger children of wealthy and noble families to take holy orders, Giuseppe joined the Teatine order at the age of 19. We do not have firsthand documents about his early studies, but we know from documents preserved in the Archive of the Palermo Observatory that between 1770 and 1780 he was requested by his superiors to teach philosophy and mathematics in many different Italian cities, including Rome, Genoa, and Ravenna. In 1781, he was appointed to the Chair of Mathematics in the newly established Accademia dei Regi Studi of Palermo (which became the University of Palermo in 1806); a few years later, in 1787 , he was named to the Chair of Astronomy even though he was not yet even an amateur astronomer. In a matter of only a few years, however, he was to become one of the most respected astronomers of his time (Fig. 1).

In March 1787, soon after he was charged with overseeing the construction of a new observatory at Palermo, Piazzi departed for a three-year stay at the major astronomical centers of Paris and London. During his travels he gained the esteem and friendship of some of the most reputed astronomers of the time, including Lalande, Messier, Mechain, Cassini, Maskelyne, and Herschel. Moreover, he succeeded in securing for the new observatory a unique instrument: the famous 5-foot circular-scale altazimuth tele- scope made by Jesse Ramsden of London (Piazzi, 1792; Pearson, 1829; Chinnici et al., 2001). Returning to Palermo in November 1789, Piazzi was able, in a matter of months, to have the new observatory built on top of the tower of Santa Ninfa at the Royal Palace.

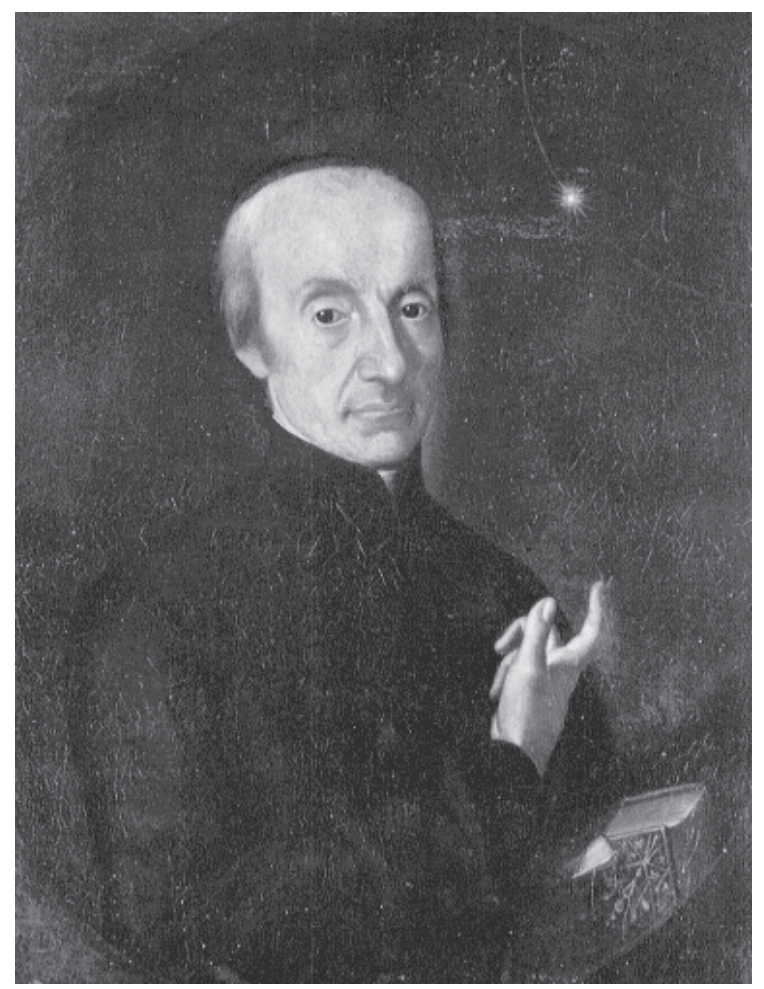

Fig. 1. Giuseppe Piazzi and Ceres. This oil portrait $(60.5 \times$ $73 \mathrm{~cm}$ ) was most likely painted at the very beginning of the nineteenth century (1803?) by the Sicilian artist Giuseppe Velasco (1750-1827), a friend of Piazzi and the author of many portraits in the Palermo Observatory collection. Courtesy of the Palermo Astronomical Observatory. 


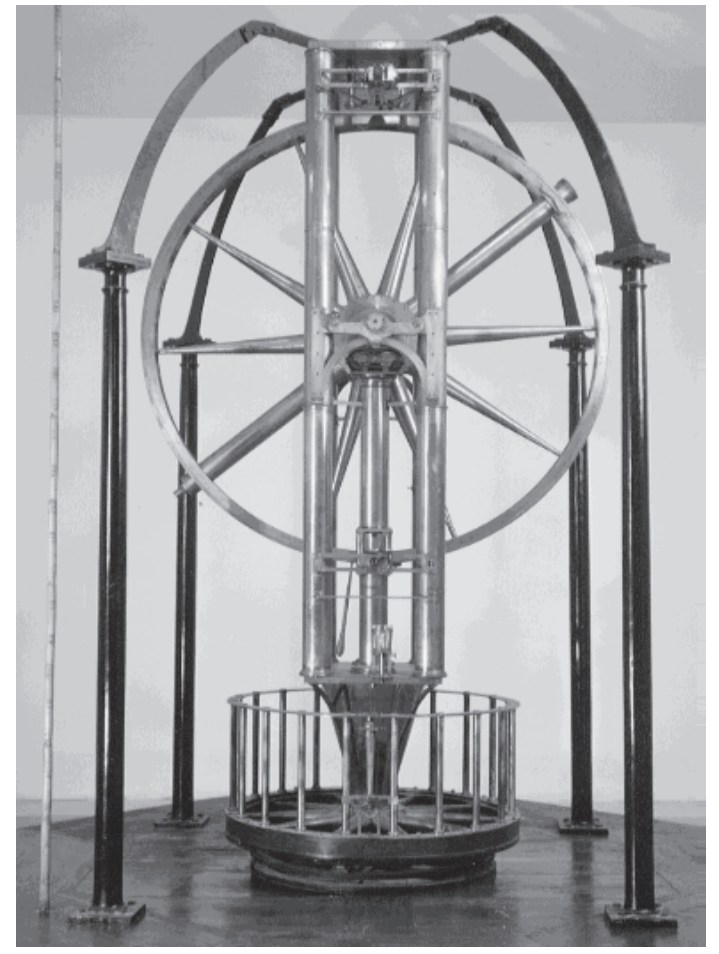

Fig. 2. The Palermo Circle by Jesse Ramsden (1730-1800), the greatest of the eighteenth-century instrument makers. With this instrument, Piazzi discovered Ceres in 1801. It was completed in 1789 after almost two years of intense work. The telescope has a 7.5 -cm objective lens; the altitude scale ( 5 feet in diameter) was read with the aid of two diametrically opposed micrometer microscopes while the azimuth scale ( 3 feet in diameter) was read by means of a micrometer microscope. Recently refurbished (Brenni et al., 2001; Chinnici et al., 2001), all the parts of the telescope are original to the time of Ceres' discovery, except for the eyepiece, which was replaced in 1855 . Reproduced by permission of the Palermo Astronomical Observatory.

Encouraged by the possession of the 5-foot Palermo Circle (Fig. 2), whose accuracy was regarded to be much superior to that of any other existing instrument (Lalande, 1803), Piazzi centered his scientific program on the accurate measurements of stellar positions. His observational technique required that each star had to be observed for at least four nights before its position could be established. This painstaking work resulted in the publication in 1803 of his first star catalog (Piazzi, 1803). For this highly regarded work, he was awarded the prize for mathematics and physics at the Institut National de France, Fondation Lalande, (Lalande, 1804) and was elected a fellow of the Royal Society. It was while working on this catalog that Piazzi, on January 1, 1801, unexpectedly discovered Ceres, the "missing planet" between the orbits of Mars and Jupiter.

\section{THE PROBLEM OF THE MISSING PLANET}

It is well known that Johannes Kepler was the first to suggest in his Mysterium Cosmographicum (1596) the ex- istence of a planet between Mars and Jupiter. Kepler's motivations for such a suggestion were of course very different from the factors that would prompt a modern scientist to make a cosmological hypothesis. The question Kepler asked himself was along the lines of, "Why had God been motivated mathematically to select the planetary orbits in the way He had?" Kepler's concern focused on the reasons the number, size, and motion of the circles were as they were and not otherwise. The gap between Mars and Jupiter was especially difficult to explain and Kepler tried a bold approach: "Between Jupiter and Mars I placed a new planet, and also another between Venus and Mercury ... Yet the interposition of a single planet was not sufficient for the huge gap between Jupiter and Mars" (Kepler, 1596).

Throughout the centuries the question of a possible explanation of this gap was taken up by such luminaries as Newton, Kant, J. H. Lambert, David Gregory, William Whiston (Newton's successor at Cambridge), and Christian Wolff (Hoskin, 1999). However, the first to invoke what is today known as the Titius-Bode Law, in the form we are familiar with, was Johann Daniel Titius, in his German translation of Charles Bonnet's Contemplation de la Nature, first published in 1766. The relation regarding the mean distances of the planets from the Sun caught the attention of Johann Elert Bode, a professional astronomer who later became director of the Berlin Observatory. Bode was convinced of the validity of such a rule and inserted it in a footnote of the second edition of his book Anleitung zur Kenntnis des gestirten Himmels, published in 1772:

This latter point seems in particular to follow from the astonishing relation which the known six planets observe in their distances from the Sun. Let the distance from the Sun to Saturn be taken as 100 , then Mercury is separated by 4 such parts from the Sun. Venus is $4+3=7$. The Earth $4+$ $6=10$. Mars $4+12=16$. Now comes a gap in this so orderly progression. After Mars there follows a space of $4+$ $24=28$ parts, in which no planet has yet been seen. Can one believe that the Founder of the universe had left this space empty? Certainly not. From here we come to the distance of Jupiter by $4+48=52$ parts, and finally to that of Saturn by $4+96=100$ parts. (Hoskin, 1993)

Because of Bode's interest and prominence, the relation assumed a new importance, especially among a small but very determined group of German astronomers. Moreover, the 1781 discovery of Uranus, whose orbit fit well into the Titius-Bode series, was a remarkable confirmation of the relation and reinforced the belief that there must be a planet between Mars and Jupiter.

One of the most determined hunters of the missing planet was Baron Franz Xaver von Zach, astronomer of the Duke of Gotha and director of the Seeberg Observatory. Von Zach's strategy to find the planet was a very reasonable one: He limited his investigations to the zodiac and produced an accurate catalog of zodiacal stars in the hope of detecting any newcomers that would fall under his telescopic field of view. He even went as far as to try to calculate a possible 
orbit of the as-yet-undiscovered planet. Von Zach's efforts, however, remained unsuccessful, and he reasoned that a cooperative attack to the problem was necessary. In September 1800, he made what he called "a small astronomical tour." He traveled to Celle near Hannover, to Bremen, and to the nearby town of Lilienthal. The purpose of this tour was to organize, with von Ende, Olbers, Gildemeister, Schroeter, and Harding, a society whose aim was to scrutinize the entire zodiac down to the smallest telescopic stars. The society was established on the afternoon of September 20, 1800, and took the name of Vereinigte Astronomische Gesellschaft, usually referred to as the "Lilienthal Society." The society's members decided to divide the zodiac into 24 zones of $15^{\circ}$ longitude and $\pm 7^{\circ}-8^{\circ}$ latitude and to allocate by lot each zone to one astronomer. It was thus necessary to ensure the cooperation of 18 other astronomers. The 24 members of the society, who became known as the "Himmels Polizei" (or "Celestial Police") (von Zach, 1801a) were J. E. Bode (Berlin), J. S. G. Huth (Frankfurt/ Oder), G. S. Klügel (Halle), J. A. Koch (Danzig), J. F. Wurm (Blauebeuren), F. von Ende (Celle), J. Gildemeister (Bremen), K. L. Harding (Lilienthal), W. Olbers (Bremen), J. H. Schroeter (Lilienthal), F. X. von Zach (Gotha), J. T. Bürg (Vienne), T. Bugge (Copenhagen), D. Melanderhielm (Stockholm), J. Svanberg (Uppsala), F. T. Schubert (St. Petersburg), J. C. Burckhardt (Paris), P. F. A. Mechain (Paris), C. Messier (Paris), C. Thulis (Marseille), N. Maskelyne (Greenwich), W. Herschel (Slough), B. Oriani (Milan), and G. Piazzi (Palermo). However, not all the astronomers appearing on this list actively participated in the society's program, nor were all of them immediately invited to be part of it. For example, no record has been found up to now that William Herschel was actually invited to actively participate (Hoskin, personal communication, 2001). Lalande, who had been invited, decided not to participate because he was "occupé du travail de la méridienne" at the time (Delambre, 1806) while von Zach's invitation letter to Barnaba Oriani was dated May 29, 1801, well after the discovery of Ceres. As for Piazzi, he never received an invitation. Von Zach, in the same letter to Oriani, wrote: "You and Piazzi were in the list of this astronomical Society that was established in September 1800 . . . . when you will write to Piazzi, invite him in the name of the Society." Quite rude behavior on the part of the Perpetual Secretary of an astronomical society!

\section{THE DISCOVERY OF CERES}

Lacking an invitation, Piazzi was totally unaware of the society's plans when at about 8:00 p.m. on January 1, 1801, while working on his star catalog, he detected what he termed a tiny star in the "shoulder" of Taurus (Piazzi, 1801). Piazzi measured its position and, as was his custom, reobserved it the following night and found that it had moved. He thought at first it was a mistake but by January 4 he was convinced it was a new "star," possibly a comet. As was customary at the time, he alerted the press the very same day. The news of the discovery of a comet was soon pub- lished by foreign newspapers, where the news was picked up by the end of February by at least two professional astronomers: Lalande in Paris and Bode in Berlin. On January 24, Piazzi, having observed the new star for a total of 14 nights, finally decided to write to Bode and to Barnaba Oriani in Milan.

The choice of writing only to Oriani and Bode may at first appear a bit strange. Oriani was his best friend, but why Bode? And why only these two? The fact is that Piazzi was not ready to commit himself as to the nature of the new star. To Oriani, he sent the positions for January 1 and January 23 plus the information that on January 11, the motion of the star had changed from retrograde to direct. But he also added a paragraph in which he stated openly that he thought that the object he had observed might have been a new planet:

I dare ... to write you, impatient as I am to give you [news]... On the 1st of January I have observed in the shoulder of Taurus a star of the 8th magnitude which, on the following night, that is the 2nd, advanced by about 3'30" northwards and about 4' towards Aries' section. I did verify my observations on the 3rd and 4th, and found approximately the same motion. On 5, 6, 7, 8, 9, the sky was covered. I did see the star again January 10 and 11, and then on $13,14,17,18,19,21,22$, and 23 . On the first observation its R.A. was $51^{\circ} 47^{\prime}$ and its northern declination was $16^{\circ} 8^{\prime}$. From 10 to 11 it turned from retrograde to direct motion, and on the observation of 23 , it had R.A. $51^{\circ} 46^{\prime}$, Dec. $17^{\circ} 8^{\prime}$. I have announced this star as a comet, but since it shows no nebulosity, and moreover, since it had a slow and rather uniform motion, I surmise that it could be something better than a comet. However, I would not by any means advance publicly this conjecture. As soon as I shall have a larger number of observations, I will try to compute its elements. (C. A., 1874) (italics added)

To Bode (1802) instead he sent the same technical information but referred clearly to the object as a comet, adding only, as a veiled suggestion, that it did not have any "appreciable nebulosity":

On January 1st I discovered a comet in Taurus, it had $51^{\circ} 47^{\prime}$ of Right Ascension, and $16^{\circ} 8^{\prime}$ of northern declination. On the 11 th its motion, until then retrograde westwards, changed into direct motion eastwards; on the 23rd it had a right ascension of $51^{\circ} 46^{\prime}$ and a northern declination of $17^{\circ} 8^{\prime}$. I shall continue to observe it and I hope to be able to observe it all along February. It is very tiny, and reaches at most a star of the 8th magnitude without appreciable nebulosity. Please, let me know if it has already been observed by other astronomers, for in this case I will not bother with the calculation of its orbit. (italics added)

Piazzi's ambiguity did not pass unnoticed. On the matter Bode (1802) later wrote: "It is absolutely incomprehensible to me why Mr. Piazzi in his letter of the same date to me calls his discovered moving star a comet, and even in some 
of the following letters insists in this opinion, disregarding my objections, and nevertheless in his first letter to $\mathrm{Mr}$. Oriani favours its planetary nature." It is evident at this point that Piazzi decided to write to Bode, who was known for helping to create the Titius-Bode law, just to probe his reaction. Unfortunately for Piazzi, the letters reached Bode on March 20 and Oriani on April 5. On February 27, Lalande, having read in the Journal de Paris that a comet had been discovered in Palermo, wrote to Piazzi asking for his observations. The letter arrived at the beginning of April and Piazzi, who had not yet received any reaction either from Bode or Oriani, was obliged to send his complete set of observations to Lalande. It should be understood that Lalande was not only a good friend of Piazzi but was also the Gran Maestro of the Lodge of the Neuf Seurs; Piazzi himself was a freemason. In other words, it was very difficult for Piazzi not to answer Lalande.

Piazzi's observations were sent on April 11 to Lalande and Oriani but not to Bode. In the meantime Bode had not been idle. As soon as he received Piazzi's letter he jumped on the idea that the object might have been the famous missing planet. He quickly calculated a circular orbit on the basis of his hypothesis about the distance and period of the supposed planet, verified that Piazzi's observations were consistent with this idea, and on March 26 gave a preliminary announcement at the Prussian Academy of Sciences. Immediately afterward he alerted von Zach, who at the time was editor of the Monatliche Correspondenz, a monthly publication designed to quickly spread astronomical news. At their first meeting after Easter, Bode presented a new memoir at the Prussian Academy. He went as far as to announce the discovery of the new planet to the press in Hamburg, Jena, and Berlin and to name it "Juno" (Bode, 1802). Von Zach was in favor of the name "Hera" proposed by Duke Ernst of Saxe-Gotha 15 years before the object's discovery (von Zach, 1801a), and this name was at first widely accepted, at least in Germany. Oriani, writing to Piazzi on July 25, 1801, said: "I have to forewarn you that

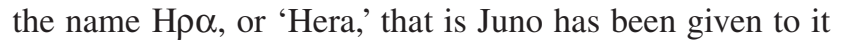
almost universally in all Germany" (C. A., 1874). Piazzi, who called his planet "Ceres Ferdinandea" in honor of the patron goddess of Sicily and of King Ferdinand of Bourbon (Piazzi, 1801), certainly did not agree. Writing to Oriani on August 25, 1801, he made no secret of his sentiment: "If the Germans think they have the right to name somebody else's discoveries they can call my new star the way they like: as for me I will always keep it the name of Cerere and I will be very obliged if you and your colleagues will do the same" (C.A., 1874). In the end, the name Ceres was accepted by the astronomical community. "As for me," wrote von Zach to Oriani on February 25, 1802, "I shall continue to call it Ceres but I beg Piazzi to drop Ferdinandea because it is a bit too long."

The young Burckhardt, to whom Lalande had passed Piazzi's observations received on May 31, immediately set to work and by June 6 sent to von Zach the elements of a circular orbit, followed three days later by those of an ellip- tical orbit (von Zach, 1801b; Bode, 1802). By the end of June the astronomical community was convinced that the "star" discovered by Piazzi was a planet. But how to reobserve Ceres once it reappeared in the morning sky in order to obtain conclusive evidence? Good ephemerides were needed. Unfortunately, the best ephemerides available at that time (derived from Burckhardt's ellipse) were not accurate enough to mount an effective search. In fact, the problem with which astronomers and mathematicians were confronted was "to determine the orbit of a celestial body, without making any hypothesis, from observations covering a space neither too large nor such as to allow the special methods to be applied" (Gauss, 1809). Because Piazzi's observations covered only $3^{\circ}$ and were so few (21) before Ceres became lost to the Sun in the evening sky, the "special methods" used by Burckhardt simply did not apply. Astronomers were growing desperate because during the month of August they had been looking for the planet without success, and, above all in France, they began to doubt the real existence of the new celestial body. In a letter to Oriani dated July 6, 1801, von Zach criticized Piazzi for having kept his observations secret for a long time, in effect preventing other astronomers from observing it and better understanding its true nature.

Reporting some suspicions, von Zach wrote:

There are some astronomers who are starting to doubt the real existence of such a star, Burckhardt suspects that the observations are very wrong, it is a fact that he gave you and Bode a Declination wrong by at least half a degree, Burckhardt says that there are other errors. Now I cannot conceive, how an observer as experienced as Piazzi, provided with the best instruments, a complete Circle, and a transit telescope by Ramsden, could incur such mistakes in his meridian observations?

In another letter to Oriani dated December 18, 1801, as yet unaware of having actually observed Ceres on December 7, von Zach asked:

What is going on with the Ceres Ferdinandea? Nothing has been found as yet either in France or in Germany. Peoples are starting to doubt: Already sceptics are making jokes about it. What is Devil Piazzi doing? La Lande wrote me that he [Piazzi] has changed again his observations and that he has made a new Edition of them! What does that mean? La Lande in his letter adds: This is why I do not believe in the planet.

In the September issue of the Monatliche Correspondenz, Piazzi's complete set of observations were finally published (Fig. 3). The young mathematician Carl Friedrich Gauss, at the time only 24, immediately seized on the importance of the problem. In the preface to his Theoria motus he wrote: "Nowhere in the annals of Astronomy do we meet with so great an opportunity, and a greater one could hardly be imagined, for showing most strikingly the value 


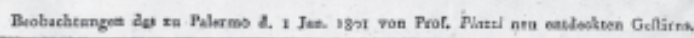

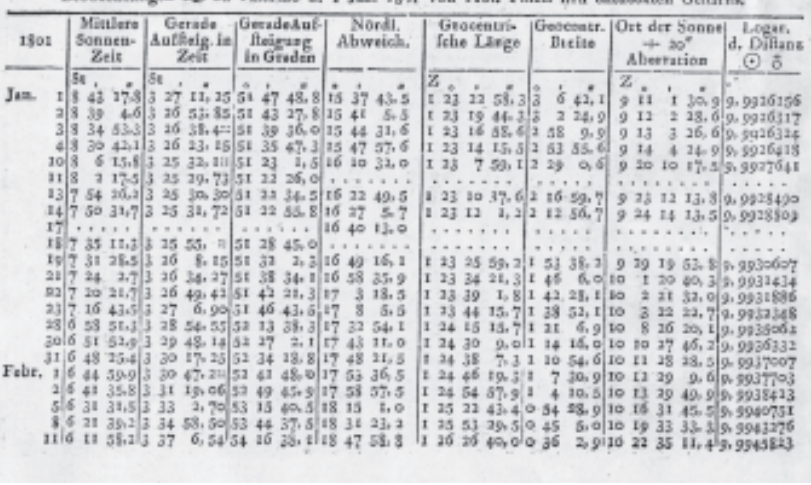

Fig. 3. Page showing Piazzi's complete set of observations as published in the Monatliche Correspondenz, September 1801, p. 280. Courtesy of the Brera Astronomical Observatory.

of this problem, than in this crisis and urgent necessity, when all hope of discovering in the heavens this planetary atom, among innumerable small stars after the lapse of nearly a year, rested solely upon a sufficient approximate knowledge of its orbit to be based upon these very few observations" (Gauss, 1809). In a matter of a little more than a month, he produced what was termed by von Zach a "perfect ellipse" (Bode, 1802), and his computed elements and ephemerides (von Zach, 1801c), in good agreement with modern values, provided positions quite different compared to the solutions that had been proposed up to then. Using these new ephemerides, von Zach directed his telescope on December 7 and actually observed Ceres, but bad weather in the following days prevented him from continuing his observations: "After Dec. 7 I have not had a clear sky. That day I observed many unknown stars, that I have not found in any catalogue not even in the one in folio that Bode has recently published... On Dec. 16th there was a break in the clouds and I had observed many little stars of 4 or 5 magnitude ... When No. 1 had to transit across the meridian it didn't come. Great joy! I thought I had caught this coquette Ceres but the joy lasted less than a minute since I didn't see either N. 2 or N. 3. It was a light haze that hid them from me" (Von Zach to Oriani, Dec. 18, 1801). All uncertainties were swept definitively away when first von Zach on December 31, 1801, and then Olbers, two days later in Brema, not far from Gauss' estimated position, were finally and independently able to confirm the recovery of Ceres and, using Gauss' words, "restore the fugitive to the observations."

It is interesting to read what von Zach wrote to Oriani on January 14, 1802:

I hasten to inform you, that I found the Ceres Ferdinandea on December 7 of last year. I had already published this observation in the January 1802 issue of my journal . . . without realizing then that it was the planet; but I suspected it was. On Decbr. 31, I verified the thing and my suspect star had changed its position, on January $11 \mathrm{I}$ observed it for the third time (the weather here is terrible) and I had the certainty of my finding, that I have the pleasure to announce to you ... Mr. Olbers has discovered the planet Ceres independently at Bremen, but later than me, on Jan. 2. I said independently since in truth he made the discovery as well as I did, since I had not sent him my observations, that I kept secret until after Jan.ry 11 when I was completely sure of my Discovery. . . . I hope that Piazzi, or you other Gentlemen Astronomers [taking advantage] of the beautiful Italian climate have found the planet before me.

A few months later, on March 28, 1802, Olbers in Bremen detected a second small body, Pallas, with features similar to those of Ceres but with an orbit that had higher eccentricity and inclination. On May 6, 1802, William Herschel presented to the Royal Society a memoir, "Observations on the two lately discovered celestial bodies," and on May 22 he sent to Piazzi a long letter in which he summarized the content of his memoir: "I say in my paper, that the interesting discoveries of Mr. Piazzi and Olbers have introduced to our acquaintance a new species of celestial bodies, with which hitherto we have not been acquainted" (C. A., 1874). This is one of Herschel's strokes of genius. Out of only two cases, Ceres and Pallas, and examining carefully in his memoir the principal features of planets and comets he drew the correct conclusion and proposed for these new bodies the name of "asteroids" because of their starlike appearance. Needless to say, the astronomical community was slow in accepting the ideas offerred by Herschel (1802), and the term asteroid became widely accepted only early in this century.

But what about Piazzi? What was he doing while throughout Europe astronomers debated, calculated orbits, and published papers? Piazzi simply remained idle. It has often been written that immediately after his last observation on February 11 he fell ill. While this is certainly true, and it is also true that between April and May he had to work on the meridian line of the Palermo cathedral that had to be solemnly reopened at the beginning of June, the real point is that he did not want his observations to be published before he could himself calculate an orbit, and he encountered tremendous difficulties in calculating even a circular orbit. Moreover, during the entire summer Piazzi continued to call the object a comet or "new star." This behavior puzzled and even infuriated the astronomical community. For instance, the Astronomer Royal Nevil Maskelyne in the summer of 1801 wrote to an unknown correspondent the following letter:

There is great astronomical news: Mr. Piazzi, Astronomer to the King of the two Sicilies, at Palermo, discovered a new planet the beginning of this year, and was so covetous as to keep this delicious morsel to himself for six weeks; when he was punished for his illiberality by a fit of sickness, by which means he lost the track of it; and now a german Astronomer, having got some of his observations, has calculated an orbit in our system as near as he could from such few observations, and had just informed us where 
he thinks it should be looked for in the course of the summer and autumn.

It will not be so easy to recover, as the lost Cupid, when Venus said you might spy among 20 immediately by his air and complection. But this having been only a star of the 8th at first, \& now for some months to come not bigger than the 10th or 12th will not be easily distinguished among 40.000 or 50.000 stars of similar appearance as it can be only known by its motion, which cannot be seen immediately but require observations of the relative position of several stars among which it is to be looked for.

What a deal this imprudent Astronomer has to answer for! It is now publicly proposed, in a german publication, to all Astronomers in Europe to hunt for it. (Howse, 1989)

To explain Piazzi's behavior, it is useful to recall that at the time of his appointment to the chair of astronomy, he was not an astronomer but simply a 40-year-old professor of mathematics whose lectures were appreciated and considered up to date. He could hardly be considered a mathematical scholar, as he had never published. However, he rapidly became an excellent observer and made important contributions to astronomy. In addition to his two excellent star catalogs, we may remember that in 1806, well before Bessel, he was the first to detect the unusually large proper motion of 61 Cygni and to point this star out to the astronomical community as a good candidate for parallax measurements (Foderà-Serio, 1990). Yet Piazzi never mastered theoretical astronomy. In his letters to Oriani he repeatedly asked his friend to send him the best formulae for calculating the orbits and to furnish him with explanations in order not to be obliged to "go back to the theory of attraction."

A second, more important point is related to the difficult environment in which Piazzi had to work. The establishment in Palermo of an Astronomical Observatory had been considered futile even by some of the professors of the Accademia dei Regi Studi and, in 1795, Piazzi had lost his most powerful "protector," Viceroy Prince of Caramanico. This fact left him in the power of the "envious academics" who went so far, once Ceres had been reobserved, as to circulate the tale that "Piazzi had been discovered by Ceres" (Angelitti, 1927).

\section{PALlas, JUNO, AND VESTA AND SOME REMARKS ON THE ORIGIN OF THE ASTEROIDS}

As already mentioned, on March 28 1802, Wilhelm Olbers at Bremen, while "observing with his telescope all the small stars in the wing of Virgo, to be sure of their position, so that he could more easily establish the position of the planet" [Ceres], detected a 7-magnitude star that "he was absolutely sure that was not there at the time of his first observations" [in January]. He "took its position; and continuing to observe it during two hours, he could see that it had changed place during this span of time" (Lalande, 1803). Within two days, Olbers was sure it was a new planet. He hastened to name it Pallas, and alerted Baron von Zach, who was able to observe it on April 4. In the following days he circulated his observations to the astronomical community. In this way not only was Pallas observed by many astronomers throughout Europe but the possibility that it might have been a comet, because of its hazy appearance and exceptional inclination of its orbit, was soon dismissed. It is amazing to read in the original reports how matter-of-factly the news of the discovery of another tiny planet orbiting around the Sun at about the same distance of Ceres was received by the astronomical community. For instance, von Zach, in a letter to Piazzi dated April 8, 1802 (less than two weeks after the discovery) wrote: "The star of D. Olbers, that I have had the honour to announce to you [April 5], is actually a primary Planet that revolves around the sun on a highly inclined orbit. . . . It exists then between Mars \& Ceres; \& undoubtedly many more planets of this kind must exist in the various spaces among the Planets; . . . It is to you, Eminent Confrère, that we owe all these discoveries, without your Ceres, no Pallas. Without Pallas no future discoveries by any of us. What a new field!" (Piazzi, 1802). This letter, along with many others, expresses well not only the lack of surprise with which the astronomers received the announcement of the new discovery, but also shows the community's willingness to accept that many other new bodies could exist both in orbits lying between Mars and Jupiter or "dans les differents espaces des Planétes." However, Bode's "law" remained in the mind of some astronomers as a law that could have a physical basis yet to be discovered. The first to try to save the law was the discoverer of Pallas. Beginning no later than June 1802, Olbers dealt with the problem of reconciling the existence of Pallas with the "beautiful harmonious law of planetary distances." Taking advantage of the fact that the mean distances from the Sun of Ceres and Pallas were pretty much the same, he suggested that they were fragments of a fullsized planet that had once occupied the gap between the orbits of Mars and Jupiter and had fragmented either under the action of internal forces or because of the impact of a comet: "... and if Ceres and Pallas were only pieces and big fragments of a pristine larger planet disrupted by internal natural forces or by the external impact of a comet?" (von Zach, 1802).

As a consequence, the discovery of other asteroids was expected and, in addition, their frequently observed variation in luminosity could be readily explained. In fact, as fragments of an exploded planet they were obviously "lacking roundness" and hence "in their rotation they were not always reflecting the same quantity of light" (Oriani, 1802). Olbers' theory seemed reasonable and was accepted by many astronomers who further reasoned that for a catastrophic explosion (initially at least) the orbits of all the fragments would have intersected in the place of the explosion and on the opposite side of the Sun. It was by observing constantly in the regions of Cetus and Virgo (where the orbits of Ceres and Pallas intersected) that Harding at Lilienthal discovered Juno on September 1, 1804. 
Immediately after this discovery, Hofrath Huth, in a letter to Bode dated September 21, 1804 (Bode, 1804), offered a different theory: "I hope that this [planet] is not the last one that will be found between Mars and Jupiter. I think it very probable that these little planets are as old as the others and that the planetary mass in the space between Mars and Jupiter has coagulated in many little spheres, almost all of the same dimensions, at the same time in which happened the separation of the celestial fluid and the coagulation of the other planets."

On March 29, 1807, Olbers, observing at Brema in the same regions of the sky where Ceres, Pallas, and Juno had been discovered, found his second asteroid, which Gauss named Vesta. Four "positive cases" in seven years were not a representative sample, but, in the absence of evidence to the contrary, they were enough to reinforce belief in Olbers' theory. Lagrange, in a well-known paper "Sur l'Origine des Comètes" (1812), considering that "Olbers hypothesis, however extraordinary it may appear, is nevertheless not unlikely," explored the consequences of the breaking of a planet into two or more fragments under the influence of internal forces. He found that this could add the required ellipticities and inclinations to Laplace's hypothesis on the formation of the solar system.

For nearly 40 years thereafter, no additional minor planets were added to the list, until finally K. L. Hencke, after 15 years of intense dedicated work, found Astraea in 1845. What accounted for the long interval of no discoveries? It is impossible to properly address this question here. Thus we will limit ourselves to make three points that are certainly relevant.

1. At least some astronomers, misled by Olbers' theory, concentrated their searches on a limited area in the directions of the orbital intersections between Ceres and Pallas.

2. The search for little planets was not considered a relevant scientific problem in and of itself. Because of that, many professional astronomers, while dedicating time to observations of new planets once they had been found, did not engage in systematic searches for them. For example, Delambre in 1806 wrote: "We further remark that these four planets [Uranus, Ceres, Pallas, and Juno] were found while searching for something else, and conclude that the real way to deserve and to encounter such accidents is to be occupied in some grand undertaking, which in itself is of real use, and keeps us constantly on the route to such discoveries; it is, for example, to work, as M. Piazzi, to perfect and augment the stellar catalogue, observing each star repeatedly for several days: this method has the double advantage to register in the catalogue only the reliable positions, and to evidence in the long run the planets that could still be confused among the innumerable quantity of very faint stars scattered in the sky" (Delambre, 1806).

3. Even though astronomers were open to the possibility that more planets were yet to be discovered [e.g., see the last lines of the above quotation and von Zach's letter to Piazzi (Piazzi, 1802)], the lack of suitable star maps discouraged many of them from undertaking a work that, while time-consuming, could not offer any guarantee of success. It is certainly not by chance that it was only after these became available, in the last years of the 1840s, that the discovery of new asteroids followed at a regularly increasing rate.

As asteroids began to be discovered in all parts of the sky, Olbers' theory began to be questioned. In 1857, when the number of asteroids amounted to a mere 50, Arago (1857) wrote: "The large number of these bodies known today leads one to believe that there are other causes for their birth. The intersections of pairs of orbits of the small planets are far from being all in agreement with Olbers' hypothesis; nevertheless, the interlacing of their orbits suggests an intimate relationship between many of these bodies, and this is a curious subject of research for astronomers in the phenomena they present." In the subsequent years a number of astronomers took up the subject. Among these was Daniel Kirkwood, known for having discovered the socalled Kirkwood gaps, who hypothesized that the asteroids originated from a ring of nebular mass that was prevented from forming a planet by the attractive pull of Jupiter (Kirkwood, 1867), a view favored by modern astronomers.

Acknowledgments. Unless otherwise stated, all the letters quoted are preserved in the Archives of the Brera Astronomical Observatory. We wish to thank Agnese Mandrino, archivist and librarian of the Brera Observatory, for her invaluable assistance in this research. We also thank the Brera Astronomical Observatory both for the material placed at our disposal and its financial support. The research of Giorgia Foderà Serio at the University of Palermo is funded by Ministero dell'Istruzione, dell'Università e della Ricerca.

\section{REFERENCES}

Angelitti F. (1927) Per il centenario della morte dell'astronomo Giuseppe Piazzi avvenuta il 22 luglio del 1826. Memorie della Società Astronomica Italiana, n.s., vol. III, pp. 369-395.

Arago F. (1857) Astronomie Populaire. Tome quatrième. Gide, Paris. 856 pp.

Bode J. E. (1802) Von dem neuen, zwischen Mars und Jupiter entdeckten achten Haupt planeten des Sonnensystems. In der Himburgischen Buchhandlung, Berlin. 136 pp.

Bode J. E. (1804) Aus einem Schreiben des Hrn. Hofrath Huth aus Frankfurt an der Oder vom 21, Sept. 1804. Astronomisches Jahrbuch für das Jahr 1807 nebst einer Sammlung der neuesten in die astronomischen Wissenschaften einschlagenden Abhandlungen, Beobachtungen und Nachrichten, pp. 265-267

Brenni P., Chinnici I., and Foderà-Serio G. (2001) The restoration of three large instruments of the Palermo Astronomical Observatory. Bull. Sci. Instrum., 71, 11-16.

C. A. (1874) Corrispondenza Astronomica fra Giuseppe Piazzi e Barnaba Oriani (G. Cacciatore and G. V. Schiaparelli, eds.). Univ. of Hoepli, Milano. 204 pp.

Chinnici I., Foderà-Serio G., and Brenni P. (2001) The Ramsden Circle at the Palermo Astronomical Observatory. Bull. Sci. Instrum. Soc., 71, 2-10.

Delambre J. B. J. (1806) Planète de Harding ou Junon. In Connaissance des Tems ou des Mouvemens Ce'lestes, a'li Usage 
des Astronomes et des Navigateurs pour l'An 1808, pp. 417427.

Foderà Serio G. (1990) Giuseppe Piazzi and the discovery of the proper motion of 61 Cygni. J. History Astron., XXI, 275-282.

Gauss C. F. (1809) Theoria Motus Corporum Coelestium in Sectionibus Conicis Solem Ambientium. F. Perthes et I. H. Besser, Hamburg. 228 pp.

Herschel W. (1802) Observations on the two lately discovered celestial bodies. Philos. Trans. R. Soc. London, 2, 213-232.

Hoskin M. (1993) Bode's Law and the discovery of Ceres. In Physics of Solar and Stellar Coronae: G. S. Vaiana Memorial Symposium (J. F. Linsky and S. Serio, eds.), pp. 36-46. Kluwer, Dordrecht.

Hoskin M., ed. (1999) The Cambridge Concise History of Astronomy. Cambridge Univ., Cambridge. 362 pp.

Howse D. (1989) Nevil Maskelyne: The Seaman's Astronomer. Cambridge Univ., Cambridge. 280 pp.

Invernizzi L., Manara A., and Sicoli P. (2001). L'astronomo Valtellinese Giuseppe Piazzi e la scoperta di Cerere. Fondazione Credito Valtellines, Ed. Bonazzi, Sondrio. 159 pp.

Kepler J. (1596) Prodromus dissertationum cosmographicarum continens mysterium cosmographicum de admirabili proportione orbium celestium deque causis coelorum numeri, magnitudinis, motuumque periodicorum genuinis et propiis, demonstratum per quinque regularia corpora geometrica. Excudebat Georgius Gruppenbachius, Tubingae. Translated by Duncan A. M. (1981) The Secret of the Universe. Abaris, New York. $267 \mathrm{pp}$.

Kirkwood D. (1867) Meteoric Astronomy: A Treatise on Shooting-Stars, Fire-Balls and Aerolites. Lippincott \& Co, Philadelphia. $129 \mathrm{pp}$.

Lagrange J. L. (1812) Sur l'origine des comètes. In Connaissance des Tems ou des Mouvemens Ce'lestes, a'li Usage des Astronomes et des Navigateurs pour l'An 1814, pp. 211-218

Lalande J. (1803) Bibliographie astronomique avec l'Histoire de l'Astronomie depuis 1781 jusqu'à 1802. De l'Imprimerie de la République, Paris. 916 pp.

Lalande J. (1804) Prix adjugé à M.Piazzi, de la fondation Lalande. In Connaissance des Tems ou des Mouvemens Ce'lestes, a'li Usage des Astronomes et des Navigateurs pour l'An XV, pp. 454455.
Maineri B. E. (1871) L'Astronomo Giuseppe Piazzi Notizie Biografiche, Tipografia già Domenico Salvi e Co., Milano. 135 pp.

Oriani B. (1802) Osservazioni del nuovo pianeta Pallade Olbersiana fatte al Settore Equatoriale. In Ephemerides Astronomicae Anni 1803 ad Meridianum Mediolanensem supputatae ab Angelo De Cesaris, pp. 22-34.

Pearson W. (1829) An Introduction to Practical Astronomy, Vol. 2. Longman, London. 708 pp.

Piazzi G. (1792) Della Specola Astronomica dè Regj Studj di Palermo, Libri Quattro. Dalla Reale Stamperia, Palermo. $240 \mathrm{pp}$.

Piazzi G. (1801) Risultati delle Osservazioni della Nuova Stella scoperta il dì 1. Gennajo all'Osservatorio reale di Palermo. Nella Reale Stamperia, Palermo. 25 pp.

Piazzi G. (1802) Della scoperta del nuovo pianeta Cerere Ferdinandea ottavo tra i primarj del nostro sistema solare. Nella Stamperia Reale, Palermo. 65 pp.

Piazzi G. (1803) Praecipuarum stellarum inerrantium positiones mediae ineunte saeculo XIX ex observationibus habitis in Specula Panormitana ab anno 1792 ad annum 1802. Typis Regiis, Palermo.

von Zach F. X. (1801a) Über einen zwischen Mars und Jupiter längst vermuteten, nun wohnscheinlich entdeckten neuen Hauptplaneten unseres Sonnen Systems. Monatliche Correspondenz, zur Beforderung der Erd- und Himmelskunde, III, 592-623.

von Zach F. X. (1801b) Fortgetze Nachrichten über den zwichen Mars und Jupiter längst vermuteten, nun wohnscheinlich entdeckten neuen Hauptplaneten unseres Sonnen Systems. Monatliche Correspondenz zur Beforderung der Erd- und Himmelskunde, IV, 53-67.

von Zach F. X. (1801c) Fortgetze Nachrichten über den längst vermuteten neuen Haupt-Planeten unseres Sonnen-Systems. Monatliche Correspondenz, zur Beforderung der Erd- und Himmelskunde, IV, 638-649.

von Zach F. X. (1802) Fortgetze Nachrichten über den neuen Haupt-Planeten unseres Sonnen-Systems, Palls Olbersiana. Monatliche Correspondenz, zur Beforderung der Erd- und Himmelskunde, VI, 71-95. 